\title{
Localized pigmented villonodular synovitis with hemorrhage arising from lateral meniscocapsular junction: A case report
}

\author{
Lateral menisco-kapsüler kavşaktan kaynaklanan kanamalı lokalize pigmente villonodüler sinovit: \\ Bir olgu sunumu
}

\author{
Hyunwoo Kim, MD'1D, Dong Cheul Shin, MD, $\mathrm{PhD}^{1}{ }^{10}$, Kyu Sang Lee, MD, $\mathrm{PhD}^{2}{ }^{\mathbb{D}}$, \\ II-Tae Jang, MD, PhD ${ }^{3}$, Kyujo Lee, MD ${ }^{1}$ ] \\ 1Department of Orthopedic surgery, Nanoori Suwon Hospital, Gyeonggi-do, Republic of Korea \\ ${ }^{2}$ Department of Pathology, Seoul National University Bundang Hospital, Gyeonggi-do, Republic of Korea \\ ${ }^{3}$ Department of Neurosurgery, Nanoori Gangnam Hospital, Seoul, Republic of Korea
}

\begin{abstract}
Pigmented villonodular synovitis (PVNS) is a benign tumorous condition commonly found in tendon sheathes, bursa, or joint synovium. Unlike the diffuse type which invades the entire synovium of the affected joint, synovium of localized PVNS shows relatively normal appearance. It presents nonspecific symptoms and typically progresses for a long time but acute locking phenomenon or internal derangement of knee symptoms suddenly commence in early stage. In this article, we present a 48 -year-old female patient with well-capsulated localized PVNS with intra-capsular hemorrhage occurring from the junction of the mid-body of lateral meniscus and the lateral joint capsule in the knee. It expanded and then moved to the lateral joint space, which caused pain, limitation of knee flexion and locking spontaneously. Arthroscopic complete excision, biopsy, and focal synovectomy were performed with punch and motorized shaver. Full weight-bearing with full knee range of motion was allowed at one day postsurgery. The mechanical symptom of locking and severe pain disappeared. At the clinical follow-up one month post-surgery, the symptoms were no longer present.
\end{abstract}

Keywords: Arthroscopy, knee, localized form, pigmented villonodular synovitis.

Pigmented villonodular synovitis (PVNS) is a rare condition. ${ }^{[1]}$ There are two types of PVNS. Localized (LPVNS) and diffuse (DPVNS).[2] The localized form is a proliferative disorder of the synovial tissue of
$\ddot{O} Z$

Pigmente villonodüler sinovit (PVNS) sıklıkla tendon kılıflarında, bursada veya eklem sinovyumunda bulunan benign, tümörümsü bir durumdur. Etkilenen eklemin tüm sinovyumuna yayılan diffüz tipten farklı olarak, lokalize PVNS'nin sinovyumu görece normal bir görünüm gösterir. Nonspesifik semptomlar sergiler ve tipik olarak uzun bir sürede ilerler fakat akut kilitlenme fenomeni veya diz içi bozukluk semptomları erken evrede aniden başlar. Bu yazıda, dizde lateral menisküsün orta gövdesi ve lateral eklem kapsülü bileşkesinden doğan kapsül içi hemorajisi olan, iyice kapsül içine alınmış lokalize PVNS'li 48 yaşında bir kadın hasta sunuldu. Sinovit genişledi ve sonra lateral eklem boşluğuna ilerleyerek eşzamanlı ağrıya, diz fleksiyon limitasyonuna ve kilitlenmeye neden oldu. Tam artroskopik eksizyon, biyopsi ve punch ve motorlu tıraşlayıcı ile fokal sinovektomi uyguland. Cerrahiden bir gün sonra tam diz hareket açıklığı ile tam ağırlık kaldırmaya izin verildi. Kilitlenme mekanik semptomu ve şiddetli ağrı kayboldu. Cerrahiden bir ay sonraki klinik takipte semptomlar artık yoktu.

Anahtar sözcükler: Artroskopi, diz, lokalize form, pigmente villonodüler sinovit.

the joint, bursa, or tendon sheathes. Localized PVNS of knee usually appears as a single pedunculated mass, or as a sessile mass, less frequently. ${ }^{[3]}$ Localized PVNS presents nonspecific symptoms and typically

Received: April 17, 2019 Accepted: May 15, 2019 Published online: May 30, 2019

Correspondence: Kyujo Lee, MD. Department of Orthopedic Surgery, Nanoori Suwon Hospital, 16503 Gyeonggi-do, Republic of Korea Tel: +82-31-1688-9797 e-mail: lockingplate@naver.com 
progresses for a long time before patients seek medical

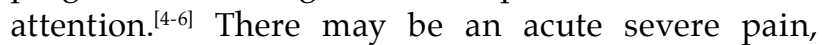
however. ${ }^{[7]}$ In this article, we report a case of LPVNS arising from the junction of the mid-body of lateral meniscus and the lateral joint capsule in the knee with an acute painful locked knee joint.

\section{CASE REPORT}

A 48-year-old female patient developed acute locking and painful swelling of her left knee joint. The patient had no history of trauma. She had been working as a major-chef at a sushi restaurant for 10 years. Physical examination showed significant amount of effusion of left knee joint. Her left knee joint was locked at $20^{\circ}$ of flexion and could not be flexed or extended because of pain. There was tenderness of anterolateral and mid-lateral joint line. Medial or lateral McMurray test or other instability tests could not be performed because of severe pain with the knee joint motion. We checked preoperative knee scores, revealing a Hospital for Special Surgery (HSS) knee score of 51 (poor), Knee Society Score (KSS) of 49 and functional KSS of 20. A written informed consent was obtained from the patient.

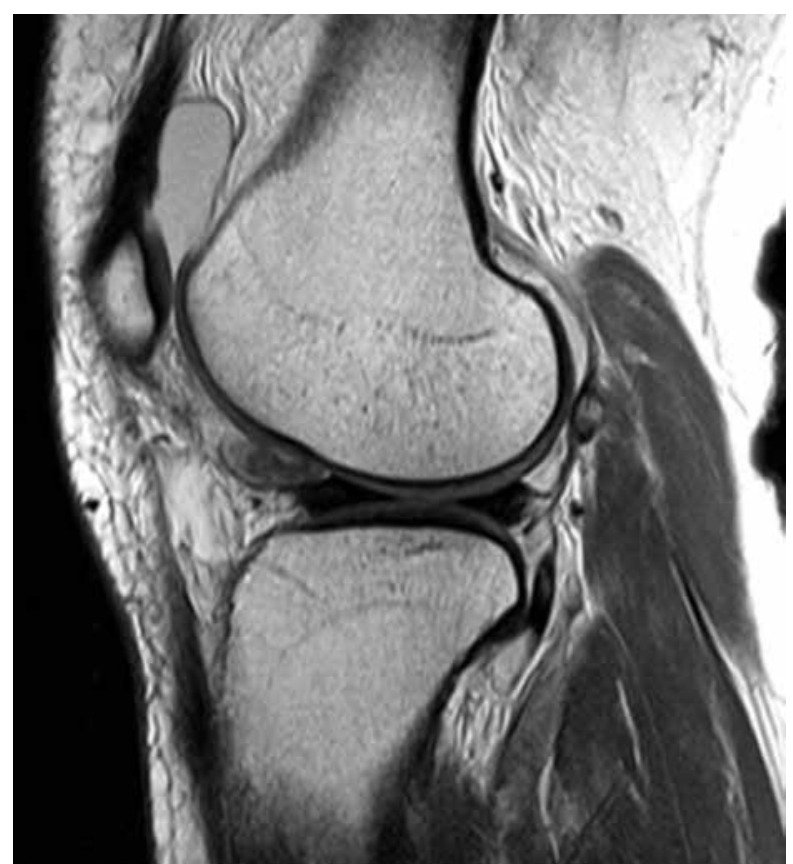

Figure 1. $T_{1}$-weighted magnetic resonance imaging showed an intra-articular soft tissue lesion, measuring $1.7 \times 1.4 \times 0.7 \mathrm{~cm}$, within the lateral joint space, located at antero-superior portion of anterior horn of lateral meniscus. Lesion had a well-circumscribed margin and showed a slightly heterogeneous signal intensity pattern. Its signal intensity was slightly lower than that of skeletal muscle on $\mathrm{T}_{1}$-weighted magnetic resonance imaging.
Laboratory tests for infection were within normal limits. Radiographs of the knee showed no remarkable features. Magnetic resonance imaging (MRI) showed an intra-articular soft tissue lesion, measuring $1.7 \times 1.4 \times 0.7 \mathrm{~cm}$, within the lateral joint space, located at antero-superior portion of anterior horn of the lateral meniscus. The lesion had a well-circumscribed margin and showed a slightly heterogeneous signal intensity pattern. Its signal intensity on $\mathrm{T}_{1}$-weighted MRI was even or slightly lower than that of skeletal muscle (Figure 1) and relatively hyperintense compared with skeletal muscle on MRI with proton density fat saturation sequences (Figure 2). Large amount of joint effusion was also noted on MRI (Figures 1, 2). The stalk of the lesion seemed to be originating from the junction of the mid-body of lateral meniscus and the lateral joint capsule on $\mathrm{T}_{2}$-weighted coronal MRI (Figure 3). We aspirated about $40 \mathrm{~mL}$ of joint fluid. The aspirated fluids were turbid and bloody with lost viscosity. On joint fluid analysis, red blood cell count was 9,920 cells $/ \mathrm{mm}^{3}$ and white blood cell count was 6,560 cells $/ \mathrm{mm}^{3}$ (neutrophil $86 \%$ ).

The patient underwent arthroscopic examination under spinal anesthesia. The examination revealed a well-capsulated mobile mass within the lateral joint space, red-brown in color with a pedunculated insertion arising from the meniscus-synovium

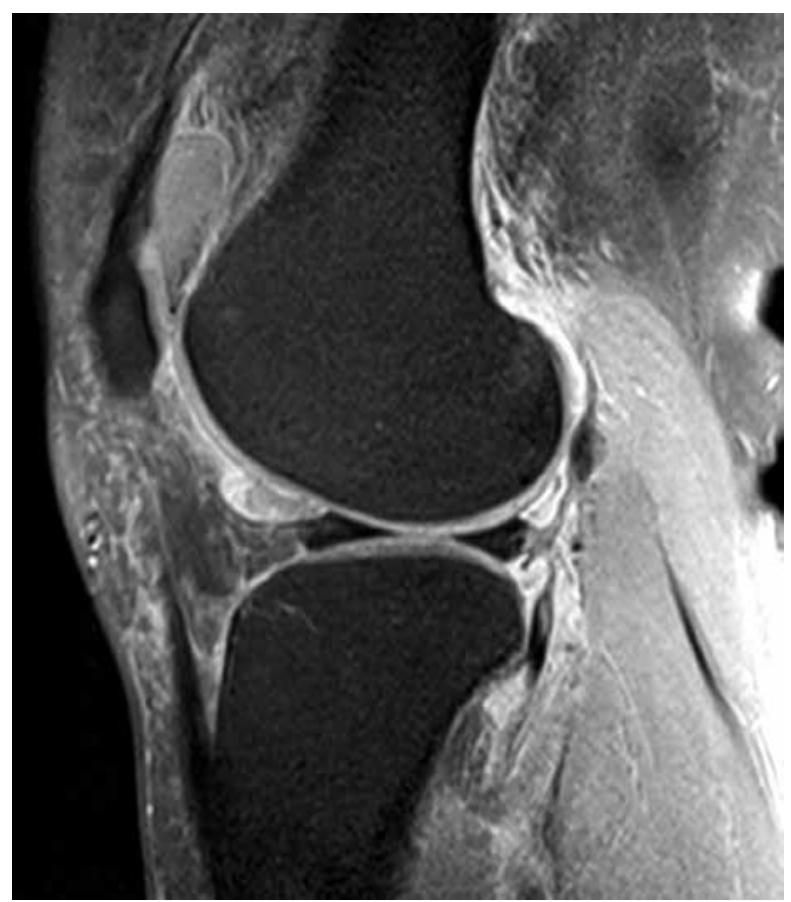

Figure 2. Signal intensity of lesion was relatively hyperintense compared with skeletal muscle on magnetic resonance imaging with proton density fat saturation sequences and joint effusion is seen. 


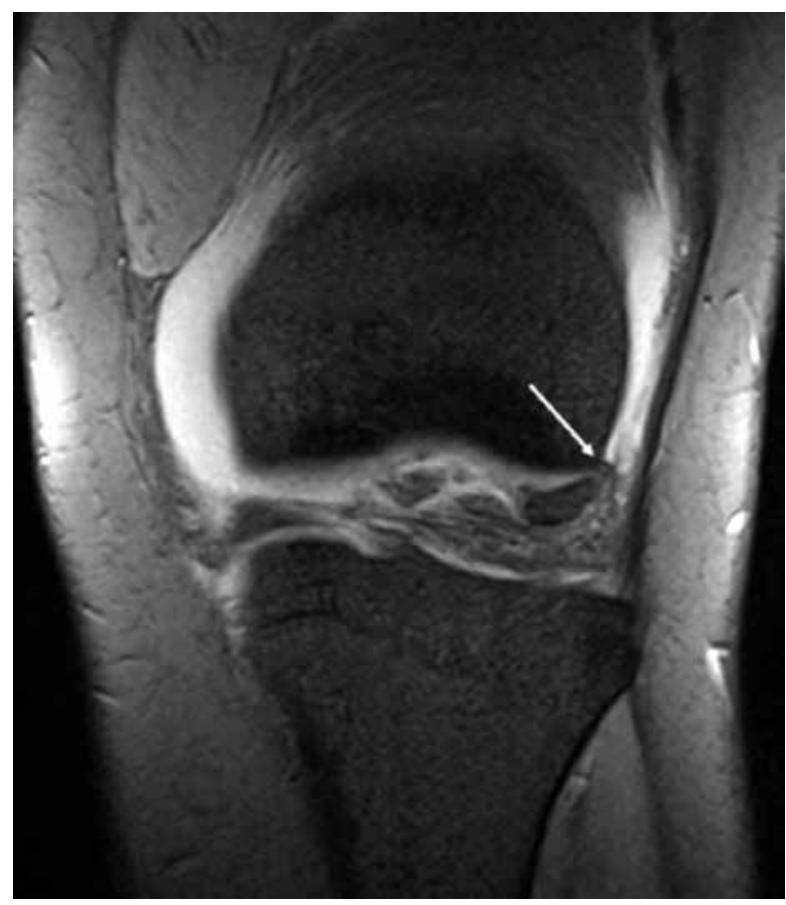

Figure 3. Stalk of lesion (arrow) seems to be originating from junction of mid-body of lateral meniscus and lateral joint capsule on $\mathrm{T}_{2}$-weighted coronal magnetic resonance imaging.

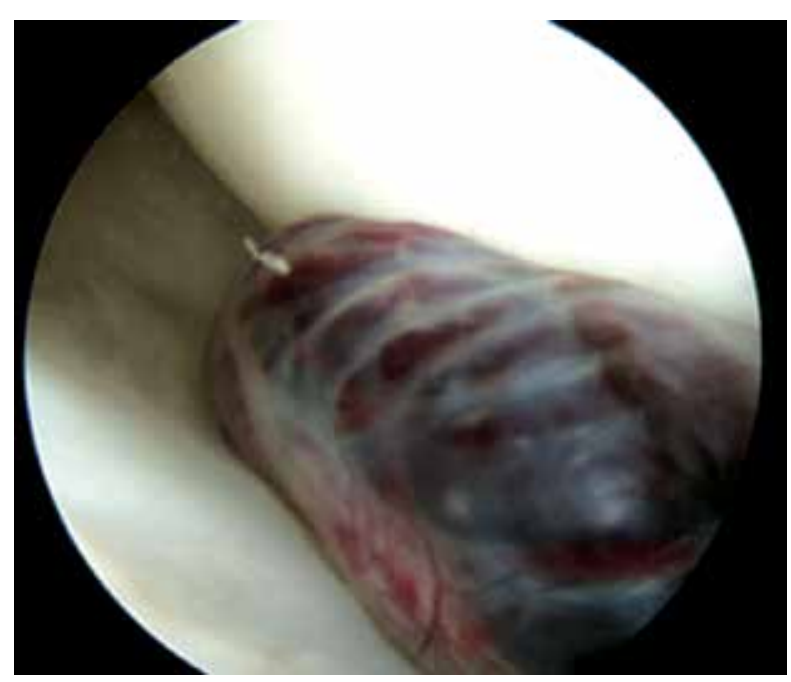

Figure 4. Intraoperative arthroscopy view of localized pigmented villonodular synovitis lesion with hematoma formation. Arthroscopy revealed a well-capsulated mobile mass within lateral joint space, red-brown in color with a pedunculated insertion arising from meniscus-synovium junction of superior side of middle part of lateral meniscus. During excision, chronic hematoma formation and acute bleeding were identified simultaneously.

junction of the superior side of the middle part of the lateral meniscus (Figure 4). The mass lesion caused mechanical block. Complete excision, biopsy, and focal synovectomy were performed with punch and

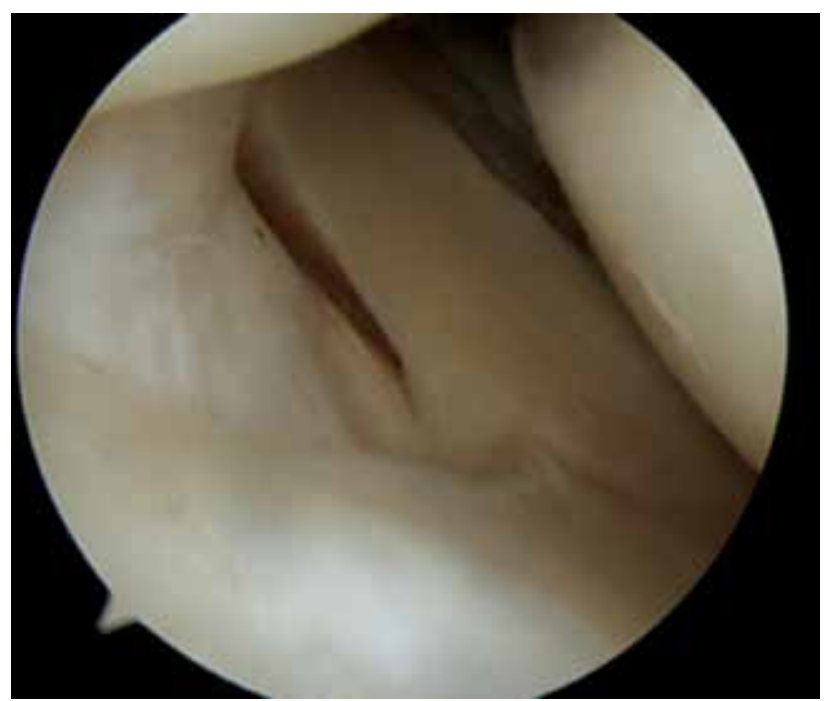

Figure 5. After removal of lesion, entire lateral joint space could be seen. Cartilage of lateral femoral condyle and lateral tibial condyle seemed to have softening and fraying portion at contact surface of lesion. Lateral meniscus was intact.

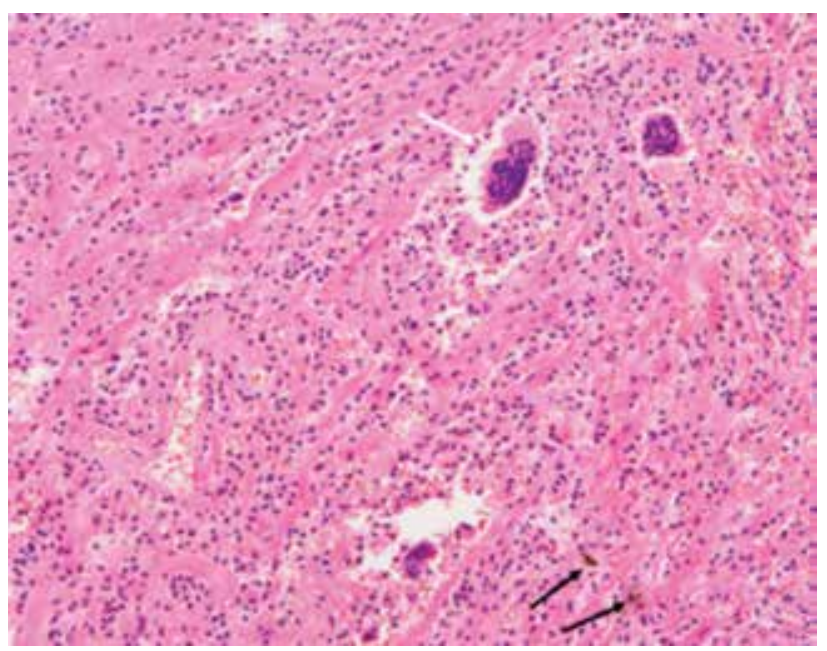

Figure 6. Histological finding shows a variable number of fibroblasts and giant cells (white arrow) with fibrosis and hyalinization. Hemosiderin deposits are also seen (black arrows) $(\mathrm{H}-\mathrm{E} \times 200)$.

motorized shaver. During excision, old blood clots from the mass and acute hemorrhage were identified at the same time. After removal of the lesion, the entire lateral joint space could be seen. The cartilage of the lateral femoral condyle and lateral tibial condyle seemed to have softening and fraying portion at the contact surface of the lesion. The lateral meniscus was intact (Figure 5). Histological analysis showed that the cell combination was consistent with villonodular synovitis: multi-nucleated giant cells with no atypical features and fibroblasts with fibrosis, hyalinization, and hemosiderin deposits (Figure 6). 
Full weight-bearing with full knee range-ofmotion was allowed at one day post-surgery. The mechanical symptom of locking and severe pain disappeared. At the clinical follow-up at one month post-surgery, the symptoms were no longer present. Postoperative knee score was checked at one month post-surgery, revealing a HSS knee score of 80 (excellent), KSS of 80 and functional KSS of 70.

\section{DISCUSSION}

Pigmented villonodular synovitis is a rare disease with benign synovial proliferation. Annual incidence has been calculated as 1.8 cases per million population. ${ }^{[1]}$ Pigmented villonodular synovitis is a part of a disease spectrum of giant cell tumor of the tendon sheath (GCTTS) and the intra-articular dominant form of GCTTS is referred to as PVNS. ${ }^{[8]}$ The etiology of the disease is unknown; however, there are three theories: ${ }^{[9]}$ neoplasia, a process associated with a disorder of the lipid metabolism, and chronic inflammation due to repeated trauma or hemorrhage. Pigmented villonodular synovitis is often localized in the knee and it is seen much less frequently in other joints. Two forms of PVNS have been described: DPVNS and LPVNS. ${ }^{[2]}$ Granowitz and Mankin ${ }^{[2]}$ were the first to provide a diagnosis of LPVNS in cases of mechanical disorder of the knee with transient pain or locking.The LPVNS is a proliferative disorder of the synovial tissue of the joint, bursa, or tendon sheaths. It is characterized by a limited impairment of the synovium, a single nodular lesion, usually pedunculated, yellow-brown in color. The lesion occasionally protrudes into the joint cavity and its size ranges between a few millimeters and $3 \mathrm{~cm}$ in diameter. ${ }^{[10,11]}$

Symptoms of LPVNS are usually non-specific, e.g. pain, warmth and swelling, and on examination tenderness and effusion are present. ${ }^{[12]}$ Symptoms typically progress for a long time before patients seek medical attention. ${ }^{[4-6]}$ However, an unusual symptom of acute severe pain or locking may occur. ${ }^{[6]}$ Mechanical symptoms of LPVNS depend on its size and location. ${ }^{[13]}$ In our case, the lesion caused limitation of knee motion because it was relatively large and located in the lateral joint space, just above the lateral meniscus. Sudden onset of acute knee pain and locking are considered to be the secondary symptoms of the accidental migration of LPVNS lesion from the lateral joint capsule into the lateral joint space.

The definitive diagnosis of PVNS can only be established after histological examination. Histologically, the lesion is characterized by a fibrous stroma, proliferation of the synovial tissue with villi or synovial nodules, deposition of hemosiderin, proliferation of round, polyhedral, histiocytic cells or spindle cells. ${ }^{[7,10]}$ Irregularly shaped multinucleated giant cells are present within the hyaline stroma. ${ }^{[7]}$

Surgical excision is considered as a treatment of choice for LPVNS. Localized PVNS has a good prognosis. In 1986, Flandry et al. ${ }^{[13]}$ presented the first case of successful arthroscopic resection of an LPVNS. Arthroscopy is the preferred technique because of the lower rate of complications and the quicker functional recovery ${ }^{[14]}$ Arthroscopy also enables the operator to diagnose with inspection of whole joint and treat associated lesions. ${ }^{[1]]}$

We performed a complete excision of the LPVNS lesion and partial synovectomy, and mechanical symptom relief was achieved just after surgery.

\section{Declaration of conflicting interests}

The authors declared no conflicts of interest with respect to the authorship and/or publication of this article.

\section{Funding}

The authors received no financial support for the research and/or authorship of this article.

\section{REFERENCES}

1. Myers BW, Masi AT. Pigmented villonodular synovitis and tenosynovitis: a clinical epidemiologic study of 166 cases and literature review. Medicine (Baltimore) 1980;59:223-38.

2. Granowitz SP, Mankin HJ. Localized pigmented villonodular synovitis of the knee. Report of five cases. J Bone Joint Surg [Am] 1967;49:122-8.

3. Kim SJ, Shin SJ, Choi NH, Choo ET. Arthroscopic treatment for localized pigmented villonodular synovitis of the knee. Clin Orthop Relat Res 2000;379:224-30.

4. Atik OŞ, Bozkurt HH, Özcan E, Bahadır B, Uçar M, Öğüt B, et al. Localized pigmented villonodular synovitis in a child knee. Eklem Hastalik Cerrahisi 2017;28:46-9.

5. Sezgin EA, Atik OŞ. Tumors and tumor-like lesions of infrapatellar fat pad and surrounding tissues: A review of the literature. Eklem Hastalik Cerrahisi 2018;29:58-62.

6. Aşik M, Erlap L, Altinel L, Cetik O. Localized pigmented villonodular synovitis of the knee. Arthroscopy 2001;17:E23.

7. Flandry F, Hughston JC. Pigmented villonodular synovitis. J Bone Joint Surg [Am] 1987;69:942-9.

8. Llauger J, Palmer J, Rosón N, Cremades R, Bagué S. Pigmented villonodular synovitis and giant cell tumors of the tendon sheath: radiologic and pathologic features. AJR Am J Roentgenol 1999;172:1087-91.

9. Donde R, Funding J. Pigmented villonodular synovitis. A follow-up study. Scand J Rheumatol 1980;9:172-4.

10. Ogilvie-Harris DJ, McLean J, Zarnett ME. Pigmented villonodular synovitis of the knee. The results of total arthroscopic synovectomy, partial, arthroscopic synovectomy, and arthroscopic local excision. J Bone Joint Surg [Am] 1992;74:119-23.

11. Calmet J, Hernández-Hermoso J, Giné J, Jimeno F. Localized pigmented villonodular synovitis in an unusual location in 
the knee. Arthroscopy 2003;19:144-9.

12. Kim RS, Lee JY, Lee KY. Localized pigmented villonodular synovitis attached to the posterior cruciate ligament of the knee. Arthroscopy 2003;19:32-5.

13. Flandry FC, Jacobson KE, Andrews JR. Localized pigmented villonodular synovitis of the knee mimicking meniscal injury. Arthroscopy 1986;2:217-21.

14. De Ponti A, Sansone V, Malcherè M. Result of arthroscopic treatment of pigmented villonodular synovitis of the knee. Arthroscopy 2003;19:602-7. 